\title{
Smallpox Vaccination: ABO and Rhesus Blood Groups
}

\section{GEOFFREY J. BOURKE, NOEL CLARKE, ${ }^{*}$ and EDWARD H. THORNTON $\dagger$}

\author{
From the Departments of Social Medicine, Pathology, and Statistics, Trinity College, Dublin, Eire
}

The hypothesis has been advanced (Pettenkofer and Bickerich, 1960) that vaccinia virus and, by implication, variola virus contain antigenic properties similar to human blood group A substance. Vogel, Pettenkofer, and Helmbold (I960) assert that possession by variola virus of a material serologically resembling human blood group A substance may have been responsible, in part, for determining the present-day global distribution of the human ABO blood groups. Pettenkofer, Stöss, Helmbold, and Vogel (I962) claim that, in smallpox infection, persons with blood groups $B$ or $O$, in whom anti-A normally occurs, have an immunological advantage over persons of blood groups $A$ and, presumably, $A B$ who lack this antibody. In support of their work these authors report that of 103 Germans with severe postvaccination reactions (more than $90 \%$ encephalitis) a significantly higher proportion belonged to blood groups $A$ and $A B$; moreover, in India and Pakistan, among 358 subjects with severe smallpox scars a similar excess of blood groups $A$ and $A B$ was demonstrated.

If the above hypothesis is correct, and recent experimental work (Harris, Harrison, and Rondle, I963) suggests that it is not, one would expect, among a group of individuals vaccinated against smallpox that: (i) persons of blood groups $B$ or $O$, who possess anti-A substance, would be more likely to resist the procedure, and present an unsuccessful vaccination, than groups $A$ or $A B$; (ii) persons of blood groups $A$ or $A B$, who do not possess anti- $A$ in their serum, would have a more severe clinical response, and might be expected to produce a larger lesion following successful vaccination, and to have a greater scar area from previous vaccination than persons of blood groups B or $\mathrm{O}$.

\footnotetext{
Received July 30, 1964.

* Present address : Department of Pathology, University College, Dublin.

† Present address: Middle East Technical University, Ankara.
}

The present study is concerned with the distri- $\vec{\omega}$ bution of the ABO and Rhesus blood groups? among a number of university students vaccinated.̧ against smallpox. The materials and methods, $i$ reading of results, and observations on clinicali reaction have already been outlined (Bourke and $\vec{N}$ Clarke, 1963, 1964).

\section{Results}

The results relate to 78I persons of the $994 \subseteq$ included in the original study, on whom ABOळ and Rhesus blood group determinations were $\vec{\circ}$ made by a tube technique. These 781 subjects have been found to be fully representative of the original group, for all pertinent data. Of theseo 781 subjects, 612 had successful vaccinations (Tables I and III), and of these 612,565 completed questionnaires relating to their symptomatologyo and to the severity of clinical reaction (Tables IV 0 and $V$ ).

It will be seen from Table $I$ that there is no significant difference between any of the $A B O$ and Rhesus blood groups in the proportion falling? into the successful and unsuccessful categories. Moreover, when groups $\mathrm{A}$ and $\mathbf{A B}$ are combinedo and compared with groups $B$ and $O$ taken together, $\frac{0}{3}$ the $\chi^{2}$ value is reduced $\left(\chi^{2}=0.380, n=1\right.$, $0.70>p>0.50$ ). Since the outcome of vaccina-O tion may be affected by country of origin and the time since the previous vaccination, it was necessary? to standardize for these factors; such corrections $>$ were found not to alter the original, negative, conclusion.

Table II shows that the scar area varies little ${ }^{\sigma}$ between the ABO groups, and that there are no $N$ significant differences between the mean scar N area of the Rhesus positive and negative groups. Similarly, in Table III the mean lesion size showso little change from one blood group to another. $\bar{\Phi}$ Corrections for period since last vaccination for? both scar area and lesion size do not alter the 0 findings.

Table IV demonstrates that in three instances statistically significant associations between blood $\stackrel{8}{\Omega}$ 
TABLE I

BLOOD GROUPS: SUCCESSFUL AND UNSUCCESSFUL VACCINATION

\begin{tabular}{|c|c|c|c|c|c|c|c|c|c|c|c|c|c|c|}
\hline \multirow[b]{2}{*}{ Vaccination Result } & \multicolumn{14}{|c|}{ Blood Groups } \\
\hline & $\mathbf{A}$ & $\%$ & B & $\%$ & $\mathbf{A B}$ & $\%$ & 0 & $\%$ & Total & $\%$ & $\mathbf{R H}+$ & $\%$ & $\mathbf{R H}-$ & $\%$ \\
\hline $\begin{array}{l}\text { Successful } \\
\text { Unsuccessful }\end{array}$ & $\begin{array}{r}225 \\
61\end{array}$ & $\begin{array}{l}78 \cdot 7 \\
21 \cdot 3\end{array}$ & $\begin{array}{l}63 \\
18\end{array}$ & $\begin{array}{l}77 \cdot 8 \\
22 \cdot 2\end{array}$ & $\begin{array}{l}16 \\
10\end{array}$ & $\begin{array}{l}61 \cdot 5 \\
38 \cdot 5\end{array}$ & $\begin{array}{r}308 \\
80\end{array}$ & $\begin{array}{l}79.4 \\
20.6\end{array}$ & $\begin{array}{l}612 \\
169\end{array}$ & $\begin{array}{l}78 \cdot 4 \\
21.6\end{array}$ & $\begin{array}{l}477 \\
136\end{array}$ & $\begin{array}{l}77 \cdot 8 \\
22 \cdot 2\end{array}$ & $\begin{array}{r}135 \\
33\end{array}$ & $\begin{array}{l}80.4 \\
19.6\end{array}$ \\
\hline Total & 286 & $100 \cdot 0$ & 81 & $100 \cdot 0$ & 26 & $100 \cdot 0$ & 388 & $100 \cdot 0$ & $78 I$ & $100 \cdot 0$ & 613 & $100 \cdot 0$ & 168 & $100 \cdot 0$ \\
\hline
\end{tabular}

ABO: $\chi^{2}=4.681, N=3,0.20>p>0.10$.

Rh: $x^{2}=0.502, \mathbf{N}=1,0.50>\mathrm{p}>0.30$.

TABLE II

BLOOD GROUPS: SCAR AREA

\begin{tabular}{|c|c|c|c|c|c|c|c|c|c|}
\hline \multirow[b]{2}{*}{$\begin{array}{l}\text { Scar Area } \\
\text { (sq. cm.) }\end{array}$} & \multicolumn{9}{|c|}{ Blood Groups } \\
\hline & A & B & $\mathbf{A B}$ & $\mathbf{O}$ & Total & $\mathbf{R h}+$ & $\mathbf{R h}-$ & $\mathbf{A}+\mathbf{A B}$ & $\mathbf{B}+\mathbf{O}$ \\
\hline $\begin{array}{l}<1 \cdot 0 \\
1 \cdot 0 \text { but less than } 5 \cdot 0 \\
5 \cdot 0 \text { but less than } 10 \cdot 0 \\
10 \cdot 0 \text { but less than } 15 \cdot 0 \\
150^{\circ} \text { but less than } 20 \cdot 0 \\
20 \cdot 0 \text { but less than } 25 \cdot 0 \\
25 \cdot 0 \text { but less than } 30 \cdot 0 \\
30 \cdot 0 \text { but less than } 35.0\end{array}$ & $\begin{array}{r}21 \\
89 \\
48 \\
16 \\
10 \\
2 \\
4 \\
2\end{array}$ & $\begin{array}{r}1 \\
30 \\
16 \\
6 \\
1 \\
1 \\
0 \\
0\end{array}$ & $\begin{array}{l}0 \\
8 \\
7 \\
2 \\
0 \\
0 \\
1 \\
0\end{array}$ & $\begin{array}{r}20 \\
110 \\
79 \\
34 \\
14 \\
1 \\
3 \\
1\end{array}$ & $\begin{array}{r}42 \\
237 \\
150 \\
58 \\
25 \\
4 \\
8 \\
3\end{array}$ & $\begin{array}{r}34 \\
189 \\
116 \\
45 \\
18 \\
2 \\
6 \\
2\end{array}$ & $\begin{array}{r}8 \\
48 \\
34 \\
13 \\
7 \\
2 \\
2 \\
1\end{array}$ & $\begin{array}{r}21 \\
97 \\
55 \\
18 \\
10 \\
2 \\
5 \\
2\end{array}$ & $\begin{array}{r}21 \\
140 \\
95 \\
40 \\
15 \\
2 \\
3 \\
1\end{array}$ \\
\hline Total & 192 & 55 & 18 & 262 & $527^{*}$ & $4^{12}$ & IIS & 210 & 317 \\
\hline $\begin{array}{l}\overline{\mathbf{x}} \\
\mathbf{p}\end{array}$ & $\begin{array}{r}6.419 \\
>0.80\end{array}$ & $\begin{array}{r}5.918 \\
>0.30\end{array}$ & $\begin{array}{r}7.166 \\
>0.50\end{array}$ & $\begin{array}{l}6.641 \\
>0.50\end{array}$ & $\frac{6.502}{-}$ & $\begin{array}{r}6.326 \\
>0.50\end{array}$ & $\begin{array}{r}7.134 \\
>0.20\end{array}$ & $\begin{array}{r}6.483 \\
>0.95\end{array}$ & $\begin{array}{r}6.515 \\
>0.95\end{array}$ \\
\hline
\end{tabular}

* 254 with no scars or scar area unknown.

TABLE III

BLOOD GROUPS: LESION SIZE

\begin{tabular}{|c|c|c|c|c|c|c|c|c|c|}
\hline \multirow{2}{*}{$\begin{array}{l}\text { Lesion Size } \\
\text { (sq. cm.) }\end{array}$} & \multicolumn{9}{|c|}{ Blood Groups } \\
\hline & $\mathbf{A}$ & $\mathbf{B}$ & $\mathbf{A B}$ & $\mathbf{O}$ & Total & $\mathbf{R H}+$ & $\mathbf{R H}-$ & $\mathbf{A}+\mathbf{A} \mathbf{B}$ & $\mathbf{B}+\mathbf{O}$ \\
\hline $\begin{array}{l}<0.5 \\
0.5 \text { but less than } 1 \cdot 0 \\
1.0 \text { but less than } 1.5 \\
1.5 \text { but less than } 2.0 \\
2.0 \text { but less than } 2.5 \\
2.5 \text { but less than } 3.0 \\
3.0 \text { but less than } 3.5 \\
3.5 \text { but less than } 4.0\end{array}$ & $\begin{array}{r}66 \\
52 \\
66 \\
16 \\
22 \\
2 \\
1 \\
0\end{array}$ & $\begin{array}{r}17 \\
19 \\
17 \\
5 \\
2 \\
1 \\
1 \\
1\end{array}$ & $\begin{array}{l}4 \\
8 \\
0 \\
0 \\
2 \\
2 \\
0 \\
0\end{array}$ & $\begin{array}{r}87 \\
90 \\
90 \\
17 \\
14 \\
4 \\
3 \\
3 \\
\end{array}$ & $\begin{array}{r}174 \\
169 \\
173 \\
38 \\
40 \\
9 \\
5 \\
4 \\
\end{array}$ & $\begin{array}{r}138 \\
123 \\
134 \\
36 \\
32 \\
7 \\
4 \\
3 \\
\end{array}$ & $\begin{array}{r}36 \\
46 \\
39 \\
2 \\
8 \\
2 \\
1 \\
1 \\
\end{array}$ & $\begin{array}{r}70 \\
60 \\
66 \\
16 \\
24 \\
4 \\
1 \\
0\end{array}$ & $\begin{array}{r}104 \\
109 \\
107 \\
22 \\
16 \\
5 \\
4 \\
4 \\
\end{array}$ \\
\hline Total & 225 & 63 & 16 & 308 & 612 & 477 & 135 & 241 & 371 \\
\hline$\underset{\mathbf{p}}{\overline{\mathbf{x}}}$ & $\begin{array}{r}0.996 \\
>0.50\end{array}$ & $\begin{array}{r}0.996 \\
>0.80\end{array}$ & $\begin{array}{r}1.662 \\
>0.50\end{array}$ & $\begin{array}{r}0.957 \\
>0.30\end{array}$ & 0.978 & $\begin{array}{r}0.991 \\
>0.50\end{array}$ & $\begin{array}{r}0.935 \\
>0.30\end{array}$ & $\begin{array}{r}I \cdot 00 I \\
>0.50\end{array}$ & $\begin{array}{r}0.964 \\
>0.50\end{array}$ \\
\hline
\end{tabular}

TABLE IV

BLOOD GROUPS: SYMPTOMS FOLLOWING SUCCESSFUL VACCINATION

\begin{tabular}{|c|c|c|c|c|}
\hline \multirow{2}{*}{ Symptoms } & \multicolumn{2}{|c|}{ ABO Blood Groups } & \multicolumn{2}{|c|}{ Rhesus Blood Groups } \\
\hline & $x^{2}$ Value & Probability $(\mathbf{N}=3)$ & $x^{2}$ Value & Probability $(\mathrm{N}=\mathbf{I})$ \\
\hline $\begin{array}{l}\text { Felt well (Yes/No) } \\
\text { Ill in bed (Yes/No) } \\
\text { Headache (Yes/No) } \\
\text { Vomiting (Yes/No) } \\
\text { General weakness (Yes/No) } \\
\text { Eyes painful in daylight (Yes/No) } \\
\text { Sore throat (Yes/No) } \\
\text { Temperature (Yes/No) } \\
\text { Pain under vaccinated arm (Yes/No) } \\
\text { Pain under unvaccinated arm (Yes/No) } \\
\text { Glands elsewhere (Yes/No) } \\
\text { Pain in back (Yes/No) }\end{array}$ & $\begin{array}{l}6 \cdot 231 \\
2 \cdot 839 \\
4 \cdot 238 \\
1 \cdot 211 \\
3 \cdot 169 \\
4 \cdot 354 \\
6 \cdot 269 \\
5 \cdot 537 \\
0 \cdot 369 \\
7 \cdot 821 \\
6 \cdot 865 \\
0.335\end{array}$ & $\begin{array}{l}>0.10 \\
>0.30 \\
>0.20 \\
>0.70 \\
>0.30 \\
>0.20 \\
>0.05 \\
>0.10 \\
>0.90 \\
<0.05^{*} \\
>0.05 \\
>0.95\end{array}$ & $\begin{array}{l}4 \cdot 838 \\
0 \cdot 013 \\
0 \cdot 961 \\
0 \cdot 071 \\
7 \cdot 098 \\
0 \cdot 555 \\
1 \cdot 419 \\
1 \cdot 759 \\
0 \cdot 338 \\
0 \cdot 015 \\
0 \cdot 387 \\
2 \cdot 898\end{array}$ & $\begin{array}{l}<0.05^{*} \\
>0.90 \\
>0.30 \\
>0.70 \\
<0.0 I^{*} \\
>0.30 \\
>0.20 \\
>0.10 \\
>0.50 \\
>0.90 \\
>0.50 \\
>0.05\end{array}$ \\
\hline
\end{tabular}

* Significant. 
TABLE V

BLOOD GROUPS: DAYS SPENT IN BED FOLLOWING VACCINATION

\begin{tabular}{|c|c|c|c|c|c|c|c|c|c|c|c|c|c|c|c|c|c|c|}
\hline \multirow{2}{*}{$\begin{array}{c}\text { No. of } \\
\text { Days Spent } \\
\text { in Bed }\end{array}$} & \multirow{2}{*}{\multicolumn{2}{|c|}{$\mathbf{A}$}} & \multicolumn{12}{|c|}{ Blood Groups } & \multirow{2}{*}{\multicolumn{2}{|c|}{$\mathbf{A}+\mathbf{A B}$}} & \multirow{2}{*}{\multicolumn{2}{|c|}{$\mathbf{B}+\mathbf{O}$}} \\
\hline & & & & $\mathbf{B}$ & & $\mathbf{A B}$ & & $\mathrm{O}$ & & Total & & $\mathbf{R H}+$ & & $\mathbf{R H}-$ & & & & \\
\hline $\begin{array}{l}\text { None } \\
\text { I } \\
2 \\
3 \\
4 \text { or more }\end{array}$ & $\begin{array}{r}21 \\
10 \\
10 \\
9\end{array}$ & $\begin{array}{c}156 \\
(75 \cdot 7 \%) \\
\\
50 \\
(24 \cdot 3 \%)\end{array}$ & $\begin{array}{l}5 \\
5 \\
1 \\
1\end{array}$ & $\begin{array}{c}50 \\
(80.6 \%)\end{array}$ & $\begin{array}{l}0 \\
0 \\
1 \\
0\end{array}$ & $\begin{array}{c}13 \\
(92 \cdot 9 \%) \\
(7 \cdot 1 \%)\end{array}$ & $\begin{array}{l}15 \\
16 \\
15 \\
13\end{array}$ & $\begin{array}{c}224 \\
(79 \cdot 2 \%) \\
\\
59 \\
(20 \cdot 8 \%)\end{array}$ & $\begin{array}{l}41 \\
31 \\
27 \\
23\end{array}$ & $\begin{array}{c}122 \\
(21 \cdot 6 \%)\end{array}$ & \begin{tabular}{|l|} 
\\
33 \\
26 \\
19 \\
17
\end{tabular} & $\begin{array}{c}347 \\
(78 \cdot 5 \%) \\
(21.5 \%)\end{array}$ & \begin{tabular}{|l}
8 \\
5 \\
8 \\
6
\end{tabular} & $\begin{array}{c}96 \\
(78 \cdot 0 \%)\end{array}$ & \begin{tabular}{|r|}
2 \\
21 \\
10 \\
11 \\
9
\end{tabular} & $\begin{array}{c}169 \\
(76 \cdot 8 \%) \\
\\
\\
5 I \\
23 \cdot 2 \%)\end{array}$ & \begin{tabular}{|l|} 
\\
20 \\
21 \\
16 \\
14
\end{tabular} & $\begin{array}{c}274 \\
(79 \cdot 4 \%) \\
\\
71 \\
(20.6 \%)\end{array}$ \\
\hline Total & & $\begin{array}{c}206 \\
(100 \cdot 0 \%)\end{array}$ & & $\begin{array}{c}62 \\
(100 \cdot 0 \%)\end{array}$ & & $(100.0 \%)$ & & $\begin{array}{c}283 \\
(100.0 \%)\end{array}$ & & $\begin{array}{c}565 \\
(100 \cdot 0 \%)\end{array}$ & & $\left(\begin{array}{c}442 \\
(100.0 \%)\end{array}\right.$ & & $(100.0 \%)$ & & $\begin{array}{c}220 \\
(100.0 \%)\end{array}$ & & $(100.0 \%)$ \\
\hline $\begin{array}{l}\overline{\mathbf{x}} \\
\mathbf{p}\end{array}$ & & $\begin{array}{l}2 \cdot 14 \\
0.30\end{array}$ & & $\begin{array}{l}1 \cdot 88 \\
0.20\end{array}$ & & $\begin{array}{l}3.0 \\
0.50\end{array}$ & $>$ & $\begin{array}{l}2 \cdot 44 \\
0 \cdot 20\end{array}$ & & $2 \cdot 26$ & & $\begin{array}{r}2.21 \\
0.50\end{array}$ & & $\begin{array}{r}2 \cdot 44 \\
>0.30\end{array}$ & & $\begin{array}{l}2 \cdot 16 \\
0.50\end{array}$ & & $\begin{array}{l}2 \cdot 34 \\
0 \cdot 50\end{array}$ \\
\hline
\end{tabular}

groups and symptoms are present. In the case of the ABO groups, association is found between pain under the unvaccinated arm, following successful vaccination, and groups $A$ and $A B$, and this association persists irrespective of whether or not these four groups are combined in pairs; furthermore, correction for differentials in country of origin and period since last vaccination does not alter the original conclusion.

With the Rhesus blood groups a significantly higher proportion of Rhesus positive subjects complained of not feeling well and of general weakness following successful vaccination. In each instance corrections were made for both country of origin and period since last vaccination, but in the case of general weakness the probability remains unaltered. When those not feeling well are considered, correction for country of origin does not affect the original result $\left(\chi^{2}=4.733\right.$, $\mathbf{n}=\mathbf{I}, 0.05>\mathbf{p}>0.02$ ), while making allowance for the period since last vaccination increases the proportion of Rhesus positive persons who felt ill $\left(\chi^{2}=7.329, \mathrm{n}=\mathrm{I}, \mathrm{p}<0.01\right)$. We must conclude then that the associations between these two symptoms and Rhesus positive persons are significant.

The mean number of days spent in bed following successful vaccination varies little between the blood groups and no significant differences are observed (Table V); correcting for period since last vaccination does not produce significant differences.

\section{Discussion}

When Pettenkofer and Bickerich (1960) demonstrated a rise in anti-A titre, in suitable rabbits, following the intravenous injection of heat-treated material prepared from the 'Berlin' strain of vaccinia virus cultured on chick chorio-allantois, it was claimed (Pettenkofer et al., 1962) that the $\frac{N}{N}$ effect was due to an antigen very similar to human $N$ blood group A substance present in vaccinia 을 virus. Harris, Harrison, and Rondle (1962) also observed a rise in anti-A titre following the inocu- $c$ lation of appropriate rabbits with extracts of $\frac{1}{\overparen{D}}$ heat-treated egg membrane infected with the $\vec{\theta}$ 'Lister' strain of vaccinia virus. On the other hand, $\mathscr{O}$ in subsequent studies (Harris et al., 1963) it was. shown that a material antigenically similar to human blood group A substance was present in uninfected eggs, and since the sera of rabbits

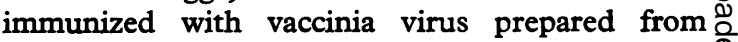
infected rabbits showed no increase in anti-A $\stackrel{\unrhd}{\unrhd}$ titre, it was inferred that the A-like substance $\overrightarrow{\vec{O}}$ considered to be present in vaccinia virus was $\frac{}{3}$ probably due to egg contaminants in the virus? preparation. It was further demonstrated that high titre rabbit anti-A did not neutralize the vaccinia virus, and experiments designed to determine the effect of human blood group sub- $\overline{0}$ stances $A$ and $B$ on the growth of the vaccinia virus on chick chorio-allantois did not indicate $\hat{O}$ that the blood group A preparation was more active in increasing the pock count of the viruso preparation than the blood group $B$ material. $D$ Thus, these authors suggested that their results would not support a hypothesis of any direct connexion between the presence of anti-A and $O$ resistance to vaccination and smallpox, and that $N$ it was improbable that the response to vaccination $N$ or susceptibility to variola would be related in a specific way to the distribution of blood group $A_{C}^{2}$ in man.

The conclusions of Pettenkofer et al. (1962) and the evidence on which they are based have also been challenged on immunological grounds $\overrightarrow{0}$ by Springer and Wiener (1962). Garlick (1960), in Nigeria, examined the blood group distribution $\stackrel{2}{\mathbb{Q}}$ 
of I49 persons who contracted smallpox and stated that it was no different from that of the general population; he was unable to demonstrate a relation between $\mathrm{ABO}$ blood group and severity of illness.

The present communication does not reveal that any individual $\mathrm{ABO}$ or Rhesus blood group is associated with success or lack of success in smallpox vaccination. It has been shown also that scar area from previous vaccination or lesion size from current vaccination varies little between the ABO groups; and there are no significant differences between the average size of lesion, or mean scar area, and the Rhesus positive and negative groups. Furthermore, no consistent pattern has been established that would suggest that persons of a particular blood group encounter a more severe vaccination reaction, including a longer stay in bed.

It is appreciated that the subjective nature of many of the criteria used to assess the severity of the clinical reactions following successful vaccination detracts from some of the conclusions drawn. In this respect the demonstrated association between groups $\mathrm{A}$ and $\mathrm{AB}$ and pain under the unvaccinated arm, indicating lymphadenitis, and the fact that a significantly greater proportion of Rhesus positive, than Rhesus negative, persons stated that they felt ill and had general weakness following successful vaccination, must be treated with caution. However, these possible associations should not be overlooked and since the probabilities of their being due to chance are greater than $I: I, 000$, they should be accepted as an indication for collecting further, and more precise, data (Roberts, I955).

In a previous study, Bourke and Clarke (1963) demonstrated that the multiple pressure technique gave a higher success rate than the scratch method in persons previously vaccinated and the difference between the success rates for the two methods was due to the greater failure of the scratch method in previously vaccinated males. Some possible explanations for this difference between the two techniques in previously vaccinated males were discussed and, though blood group distribution was not advanced as a possible cause of failure, it is apparent now that since differences in the distribution of the $\mathrm{ABO}$ and Rhesus blood groups among successful and unsuccessful vaccinations do not exist then blood groups could not have played a part in producing the observed result.

\section{Summary}

The ABO and Rhesus blood groups were determined in a group of $78 \mathrm{I}$ university students vaccinated against smallpox. There was no evidence to suggest that an individual blood group is associated with success, or lack of success, in smallpox vaccination; or that, in general, persons of a particular blood group encounter more severe reactions, though some exceptions have been demonstrated and commented upon. The mean lesion size from current vaccination does not differ significantly from one blood group to another, and a similar conclusion is reached regarding scar area from previous vaccination.

We wish to thank Dr A. E. Mourant (Blood Group Reference Laboratory, London), who kindly read the text, for helpful criticism. We are indebted to Connaught Research Laboratories Ltd. (University of Toronto) who supported this study, and $\mathrm{Mr} \mathrm{T}$. Kilbride for his assistance.

\section{REFERENCES}

Bourke, G. J., and Clarke, N. (1963). Smallpox vaccination: success rates of scratch and multiple pressure techniques. Brit. med. F., $2,28 \mathrm{I}$.

$\longrightarrow$, and - (1964). Some observations on clinical reactions following smallpox vaccination. Irish F. med. Sci., 75 .

Garlick, J. P. (1960). Blood Groups and Sickling in Nigeria. Ph.D. thesis, University of London. Cited in Lancet (1962). I, 626.

Harris, R., Harrison, G. A., and Rondle, C. J. M. (I962). Vaccinia virus and human blood-group-A substance. Lancet, I, 622.

$\longrightarrow$ - - and - (1963). Vaccinia virus and human bloodgroup-A substance. Acta. genet. (Basel), $13,44$.

Pettenkofer, H. J., and Bickerich, R. (I960). Über Antigen-Gemeinschaften zwischer den menschlichen Blutgruppen ABO und den Erregern gemeingefährlicher Krankheiter. Zbl. Bakt., I. Abt. Orig., 179, 433.

-, Stöss, B., Helmbold, W., and Vogel, F. (1962). Alleged causes of the present-day world distribution of the human $\mathrm{ABO}$ blood groups. Nature (Lond.), 193, 445.

Roberts, J. A. F. (1955). Discussion on the ABO blood groups and disease. The biometrical approach. Proc. roy. Soc. Med., 48, 143.

Springer, G. F., and Wiener, A. S. (1962). Alleged causes of the present-day world distribution of the human $A B O$ blood groups. Nature (Lond.), 193, 444.

Vogel, F., Pettenkofer, H. J., and Helmbold, W. (1960). Über die Populationsgenetik der ABO-Blutgruppen. Acta genet. (Basel), 10, 267. 